\title{
Improving the Community Participation in Safe Management of Disinfectant and Plastic Waste During the Covid 19 Pandemic in Banjarbaru
}

\author{
Dian Rosadi *, Lenie Marlinae *, Syamsul Arifin *, Laily Khairiyati *, Agung Waskito *, Noor Ahda Fadillah *, \\ Anugrah Nur Rahmat*, Raudatul Jinan**, Ammara Ulfa Azizah**, Winda Saukina S.J** \\ * Lecturer of Public Health Study Program, Facukty of Medicine, Lambung Mangkurat University, Indonesia \\ ** Student of Public Health Study Program, Facukty of Medicine, Lambung Mangkurat University, Indonesia
}

DOI: 10.29322/IJSRP.10.12.2020.p10828

http://dx.doi.org/10.29322/IJSRP.10.12.2020.p10828

\begin{abstract}
Covid-19 prevention and controling with the behavior of wearing masks continuously during activities outside of home and reinforced by healthy living behavior (PHBS) before and after activities outside of home. This activity has started in early April 2020 until now. With 262,719 population of Banjarbaru, It is estimated that the volume of mask waste every day is $44,072,745 \mathrm{~kg} /$ day. While in every month is $1,322,182.35 \mathrm{~kg} /$ month. Then another problem is the use of hand washing soap with 1 to 2 $\mathrm{ml}$, that usage of that about $6 \mathrm{ml}$ every day, and daily is $25,823,874 \mathrm{ml}$. The strategy used in this program is the ABG community approach (Advocacy, Community Development and Community Movement). Activities through the Whatsapp Group containing participants of the Kemuning Village, Banjarbaru. The media used in socialization are booklets and leaflets that are delivered to participants. The pre-post test results of 20 people had an increase in knowledge which increased from 5.45 to 8.55 .
\end{abstract}

Index Terms- Covid-19, solid waste, liquid waste.

\section{INTRODUCTION}

$\mathrm{T}$ The SARS-CoV-2 (COVID-19) virus pandemic, which was first discovered in the Chinese city of Wuhan at the end of 2019, now has spread to 210 countries and 2 international cruise ships. Reported positive cases of the corona virus in the world, have infected around 3.4 million people with the death of nearly 240 thousand people and it is predicted that this number will continue to grow (Worldometer, 2020).

In Indonesia, the corona virus was found that have started to spread in early March 2020 and currently there have been 10,551 positive cases with the death of 800 people (Worldometer, 2020). The corona virus spreads through droplets of positive people's fluids when coughing or sneezing and this corona virus can last up to 9 days on the surface of objects. That explained how the corona virus can quickly spread. Many efforts that have been made by the government to decrease the spread of the corona virus, for an example is social distancing
Covid-19 prevention and control activities with the behavior of wearing masks continuously during activities outside of home and reinforced by healthy living behavior (PHBS) before and after activities outside of home. This activity has started in early April 2020 until now. It is assumed that the weight of 1 medical mask is 3.2 grams, with a population of Banjarbaru that is 262,719 people, the estimated volume of mask waste every day is $44,072,745 \mathrm{~kg} /$ day. And every month is $1,322,182.35 \mathrm{~kg} /$ month.

Then another problem is the use of hand washing soap with different chemical content with $90 \%$ surfactant content. With 1 to $2 \mathrm{ml}$ usage of 1 to $2 \mathrm{ml}$ and daily usage of that about $6 \mathrm{ml}$ every day is $25,823,874 \mathrm{ml}$.

The impact of that thing is expected to be experienced by human health and the environment due to the process of human behavior that associated with waste that is corrosive to the skin, eroding the skin layer, hormonal imbalance and increasing the incidence of breast and ovarian cancer, the negative impact on water can reduce the quality of water and odor from the soil reduce the nutrients so the plants cannot grow as they should. Impact on air quality, if the results of combustion from both the incinerator and non-incinerator are not suitable, it will cause new problems in the form of air pollution due to dioxins and other dangerous compounds and anticipate disasters due to waste during the Covid-19 pandemic.

In addition, it is necessary to make efforts in waste management before it is destroyed, because bisidesi o containing hazardous materials such as B3 it is also can be a medis of transmission as well as the transmission of microorganisms, therefore it is necessary to know how to handle it properly and so it will not have an impact on human also the environment.

Based on the description above, it is necessary to have continuous attention and understanding of environmental hygiene and health through health education activities about the management of disinfectant waste from hand washing and plastic through management and collaboration by carrying out community-based management activities so that all problems can be handled properly and produce an healthy environment and not became a covid 19 transmission. 


\section{RESEARCH METHOD}

The strategy used in this program is the $\mathrm{ABG}$ community approach (Advocacy, Community Development, and Community Movement). Conducting socialization via WhatsApp to work groups and the community online because of paying attention to the Covid 19 protocol so that people will get the information about the process and management methods, especially the management of disinfectant waste from hand washing and plastic through media that shared by online.

The supporting media that we used for work groups and the community due observance of the Covid 19 protocol are the booklets and leaflet about the process and management of disinfectant waste from hand washing and plastic waste , especially the management method in pandemic Covid 19.

The participants that involved are 20 people of Banjarbaru are live on Kemuning village. They are agree to be participant and join in WhatsApp group that already made and actively involve in socialization, also fill all of questionary that are made.

Short-term evaluation was assessed to determine public knowledge about the application of environmental health principles in the management of disinfectant waste from hand washing and plastic waste in Pandemic Covid19 are using a pre-test and post-test questionnaire which then the result will compared to see are the media that given will effect or not.

\section{FINDINGS}

Table 1. Distribution of Respondents Age

\begin{tabular}{lll}
\hline Respondent Age & Amount $(\mathbf{n})$ & Percent $(\%)$ \\
\hline $17-25$ years & 6 & 30 \\
\hline $26-35$ years & 4 & 20 \\
\hline $36-45$ years & 4 & 20 \\
\hline $46-55$ years & 6 & 30 \\
\hline amount & 20 & 100 \\
\hline
\end{tabular}

Table 2 Distribution of Respondents Gender

\begin{tabular}{lll}
\hline Gender & Amount (n) & Percent (\%) \\
\hline Male & 9 & $45 \%$ \\
\hline Women & 11 & $55 \%$ \\
\hline Amount & 20 & $100 \%$ \\
\hline
\end{tabular}

Table 3 Distribution of Respondents Education

\begin{tabular}{lll}
\hline Education & Amount (n) & Percent (\%) \\
\hline Elementry sccool & 1 & 5 \\
\hline Middle school & 1 & 5 \\
\hline High school & 10 & 50 \\
\hline $\begin{array}{l}\text { D1 / D2 / D3 / S } \\
\text { / M }\end{array}$ & 8 & 40 \\
\hline amount & 20 & $100 \%$ \\
\hline
\end{tabular}

Table 4. Distribution of Knowledge Score on Pre Test

\begin{tabular}{lll}
\hline Category & Amount (n) & Percent (\%) \\
\hline $\mathrm{Bad}$ & 11 & 55 \\
\hline
\end{tabular}

\begin{tabular}{lll}
\hline Category & Amount (n) & Percent (\%) \\
\hline Good & 9 & 45 \\
\hline amount & 20 & $100 \%$ \\
\hline \multicolumn{2}{l}{ Table 5. Distribution of Knowledge Score on Post Test } \\
\hline Category & Amount (n) & Percent (\%) \\
\hline Bad & 0 & 0 \\
\hline Good & 20 & 100 \\
\hline amount & 20 & $100 \%$ \\
\hline
\end{tabular}

Table 6 Distribution of Respondents Knowledge Level Table

\begin{tabular}{ll}
\hline Category & Average \\
\hline Pre-test & 5.45 \\
\hline Post-test & 8.55 \\
\hline Amount & 10 \\
\hline
\end{tabular}

\section{DISCUSSION}

Before the activity was carried out, it was known that the estimation of Banjarbaru waste from the results of the Banjarbaru Environmental Service Agency report in 2020 was 166 tons / day, there were 144 tons to the TPA (handling), 20 tons of reduction and 2 tons of unserved. Organic waste (food waste and leaves) as much as $61.67 \%$, plastic waste as much as $14.08 \%$ as much as $14.08 \%$, cloth / textile waste as much as $11.60 \%$, paper waste as much as $8.74 \%$, glass / glass waste as much as $1,98 \%$, metal waste as much as $0.94 \%$, rubber waste as much as $0.44 \%$, electronic waste as much as $0.31 \%$, wood waste as much as $0.21 \%$ and other waste as much as $0.03 \%$.

Based on table 1, it is known that the age of the respondents for the service of waste management efforts during the Covid19 pandemic in the Kemuning Village consists of 4 age categories according to the category of the Indonesian Ministry of Health in 2009, namely 6 people $(30 \%)$ in the late adolescent category (17-25 years), 4 people $(20 \%)$ in the category of early adulthood (25-35 years), 4 people (20\%) in the category of late adulthood and 4 people $(30 \%)$ in the category of early elderly (46-55 years) .

Based on table 2 shows that the gender of male respondents is 9 people $(45 \%)$, and the gender of female respondents is 11 people (55\%).

Based on table 3, it shows that the education of the respondents who graduated from Elementery School was 1 person (5\%), 1 person (5\%) are Middle School graduates, High School graduates are 10 people $(50 \%)$ and 7 people are D1 / D2 / D3 / Bachelor / Masters graduates (40\%).

Based on table 4, it shows that the frequency of knowledge scores on Pre Test is 11 people $(55 \%)$ are Bad, and the frequency of good knowledge scores on Pre Test are 9 people $(45 \%)$.

Based on table 5, it shows that the frequency of knowledge scores on Post Test is none of people $(0 \%)$ is $\mathrm{Bad}$, and the frequency of good knowledge scores on Post Test are 20 people $(100 \%)$. 
The level of knowledge based on the correct answer chosen by the respondent when filling out the pre-post test questions. By the 10 questions, the level of knowledge is good if it answer 6-10 questions correctly, and bad if you answer 1-5 questions correctly.

Based on table 6 , it shows that all 20 respondents have increased knowledge. This can be seen from the increase in the respondents' knowledge average score from only 5.45 to 8.55 after the socialization.

\section{CONCLUSION}

Based on the research, it was concluded that in socialization on disinfectant and plastic waste management, the media that are booklets or pocket books and leaflets were used. From the results based on the results of the pre and post test questionnaires that were filled in by the respondents, it can be seen that the media has an effect on increasing the respondents' knowledge. After there is an increase in knowledge by the respondents, it is hoped that this can affect the attitude of the respondents in managing disinfectant waste and plastic waste during the Covid-19 Pandemic.

\section{REFERENCES}

Chandra, Budiman. 2006. Introduction to Environmental Health. Medical Book EGC: Jakarta

Depkes RI 1996. Implementation Guidelines for Monitoring and Controlling the Impact of Waste (Environmental Health Aspects. EGC: Jakarta.

Nurhidayat, Setyo Purwendro. 2010. Managing Waste for Fertilizers and Organic Pesticides. Self-help spreader: Jakarta

Djabu, U. 2001. Guidelines for the Study of Fecal and Wastewater Development at Environmental Health Sanitation Education Institutions. Jakarta: MOH RI Health Workforce Education Center

Dimedjo, SS 2005. Introduction to the Study of Dirty Water Management. Jakarta: Pusdiknakes

Ginting, P. 2002. Waste Treatment Technology. Jakarta: Publishers of Pustaka Sinar Harapan

\section{AUTHORS}

First Author - Dian Rosadi, Lecturer, Public Health Study Program, Faculty of Medicine, Lambung Mangkurat University, Indonesia

Second Author - Lenie Marlinae, Lecturer, Public Health Study Program, Faculty of Medicine, Lambung Mangkurat University, Indonesia

Third Author - Syamsul Arifin, Doctor, Lecturer, Public Health Study Program, Faculty of Medicine, Lambung Mangkurat University, Indonesia

Fourth Author - Laily Khairiyati, Lecturer, Public Health Study Program, Faculty of Medicine, Lambung Mangkurat University, Indonesia

Fifth Author - Agung Waskito, Lecturer, Public Health Study Program, Faculty of Medicine, Lambung Mangkurat University, Indonesia

Sixth Author - Noor Ahda Fadillah, Lecturer, Public Health Study Program, Faculty of Medicine, Lambung Mangkurat University, Indonesia

Seventh Author - Anugrah Nur Rahmat, Lecturer, Public Health Study Program, Faculty of Medicine, Lambung Mangkurat University, Indonesia

Eighth Author - Raudatul Jinan, Student, Public Health Study Program, Faculty of Medicine, Lambung Mangkurat University, Indonesia

Ninth Author - Ammara Ulfa Azizah, Student, Public Health Study Program, Faculty of Medicine, Lambung Mangkurat University, Indonesia

Tenth Author - Winda Saukina S.J, Student, Public Health Study Program, Faculty of Medicine, Lambung Mangkurat University, Indonesia

Correspondence Author - Dian Rosadi, Public Health Study Program, Faculty of Medicine, Lambung Mangkurat University, Indonesia, email: dianrosadi@ulm.ac.id 